This is the peer reviewed version of the following article: Cohen-Almagor, R. (2011), Fighting Hate and Bigotry on the Internet. Policy \& Internet, 3: 1-26, which has been published in final form at doi:10.2202/1944-2866.1059. This article may be psed for non-commercial purposes in accordance With Wiley Terms and Conditions for self-archiving.

\title{
Fighting Hate and Bigotry on the Internet
}

\section{Raphael Cohen-Almagor ${ }^{1}$}

\begin{abstract}
Hate speech is a specific type of online content that is designed to threaten certain groups publicly and act as propaganda for offline organizations. Hate groups use websites for sharing ideology, propaganda, link to similar sites, recruit new converts, advocate violence and threat others. The aim of this paper is to analyse the ways Nethate can be countered. It is written and argued in the realm of ethics, or rather applied ethics. It offers a discussion on moral and social responsibility. Unfortunately, this is a neglected issue in the literature.
\end{abstract}

This study focuses on articulating possible solutions to specific problems and on providing a framework within which these problems can be identified and resolved by accentuating moral and social responsibility. Section II introduces the underpinning concepts of this essay, moral and social responsibility. Section III discusses the targets of hate on the Internet. Finally, Section IV offers practical proposals to address this increasing problem and fight against it. Socially responsible people should not stand

\footnotetext{
1 I thank Janet Spikes and Marco Zambotti for their excellent research assistance, and Rabbi Abraham Cooper, Oren Segal and Holly Hawkins for providing me with invaluable information. Much of this research was conducted under the generous auspices of The Woodrow Wilson International Center for Scholars. I thank Steve Newman, Robert Fortner, Wayne Sumner, the participants of Hate versus Democracy on the Internet conference, Fordham Center on Law and Information Policy, NY (March 2010) and the reviewers of Policy and Internet for their constructive comments. All websites were accessed during February 2010.
} 
idly by while others are abusing the Net to discriminate and victimized their targets for hate.

Keywords: Aristotle, bigotry, hate speech, Nethate, social responsibility 


\section{Introduction}

The Internet has become an invaluable part of our lives. About a quarter of humanity, more than 1.7 billion people, use the Internet for social, financial, educational, medical, recreational, political and military reasons. It is hard to think of a single aspect of life that is not supported by the Internet. As access to the Internet became less costly and creating Web pages a relatively simple task, the number of Web sites and Net users has grown exponentially.

The Internet contains the best and the worst products of humanity. It is open for use and abuse. As the Internet provides cheap, instantaneous and decentralized distribution, multiple points of access, no necessary tie to geography, no simple system to identify content as well as tools of encryption, the Internet has become an asset for hate groups to transmit propaganda and provide information about their aims, allow an exchange between like-minded individuals, vindicate the use of violence, raise cash, legitimize their actions while demoralize and de-legitimize others. With the advent of the Internet, opportunities for disseminating hate proliferate.

Hate speech is defined as a bias-motivated, hostile, malicious speech aimed at a person or a group of people because of some of their actual or perceived innate characteristics. It expresses discriminatory, intimidating, disapproving, antagonistic and/or prejudicial attitudes toward those characteristics which include sex, race, religion, ethnicity, colour, national origin, disability, or sexual orientation. Hate speech is aimed to injure, dehumanize, harass, intimidate, debase, degrade, and victimize the targeted groups, and to foment insensitivity and brutality against them. Hate site is defined as a site that carries hateful message in any form of textual, visual, or audiobased rhetoric. 
The line-drawing of what constitutes hate is not always simple. On the one hand, statements that assert "Jews are money hungry," "gays are immoral," "abortionists are murderers," "Israel is an apartheid state," "niggers return to Africa," and calls to boycott Israel $^{2}$ are all unpleasant yet legitimate speech. On the other hand, calls that incite violence against target groups fall under the definition of incitement; here the context is of harmful speech that is directly linked to harmful action. Thus, when we speak of hate speech we speak of malicious speech that is aimed to victimize and dehumanize its target, often (but not always) vulnerable minorities. Hate speech is fuzzier than incitement and concretely more damaging than advocacy. Hate speech creates a virulent atmosphere of "double victimization": The speakers are under attack/misunderstood/marginalized/delegitimized by powerful forces (governments, conspiratorial organizations); the answer to their problem is the victimization of the target group. Their victimization is the speakers' salvation.

The object of this Essay is to not to contest law. It is written and argued mainly in the realm of ethics, or rather applied ethics. It offers a discussion on moral and social responsibility. Unfortunately, this is a neglected issue in the literature. The prevailing discussions' raison d'être is freedom of expression from legal/New Media perspectives with little attention to the notion of responsibility. The Essay addresses the ethical problems rooted in technology in response to potential risks on the Internet. The Internet is not the problem. The problem arises where it is utilized to undermine our well-being as autonomous beings living in free societies. This study focuses on articulating possible solutions to specific problems and on providing a framework within which these problems can be identified and resolved by accentuating moral and

\footnotetext{
2 Boycott Israeli Apartheid http://apps.facebook.com/causes/809?m=de0957a2
} 
social responsibility. Section II introduces the underpinning concepts of this essay, moral and social responsibility. Section III discusses the targets of hate on the Internet. Section IV offers practical proposals to address this increasing problem and fight against it. Socially responsible people should not stand idly by while others are abusing the Net to discriminate and victimized their targets for hate.

The article's methodology is based on extensive review of the literature, study of dozens of hate sites as well as interviews and discussions I held in Canada, the USA, Israel and England during 2006-2010. ${ }^{3}$ This is not an easy study, not only because of its troubling and quite upsetting content but also because the sites are very volatile. One study named more than thirty blogs in 2007. None was in existence when I am writing this essay, some three years later. ${ }^{4}$ Raymond A. Franklin compiled "The Hate Directory" in October 2002. The Directory is comprised of hundreds of web pages, file archives, mailing lists (listservs), news groups, Yahoo clubs and groups, MSN groups, and racist games. I tried to access each of the links of the 95-page long Directory. The vast majority of the links were not operative in February-March 2010. The information is like a moving target and needs to be updated all the time. The discussion groups are in flux; sometimes they are illusive, changing names and locations all the time.

In November 2009, Franklin published an updated version of the Hate Directory, ${ }^{5}$

\footnotetext{
${ }^{3}$ One interview was held in 2002.

4 Michael Chau and Jennifer $\mathrm{Xu}$, "Mining communities and their relationships in blogs: A study of online hate groups," Int. J. Human-Computer Studies 65 (2007): 57-70.

5 Raymond A. Franklin, "The Hate Directory" (November 1, 2009), http://www.hatedirectory.com/hatedir.pdf; http://www.hatedirectory.com/
} 
exist, or were relocated to other servers. One thing is certain: Hate is a steadily growing phenomenon on the Net.

Of course, it is not only the number of the sites that is of importance. Of no less importance is the quality of the site in terms of its design, attractiveness, content and prominence, i.e., the number of hits that the site gets. For instance, one hate site, Stormfront.org, has thousands of hits each and every day. ${ }^{6}$

which is almost doubled in size, 170 page long; but many of the sites ceased soon to

6 Steve Newman commented: While I agree that the number of hits each site gets is worrying, we cannot assume that each of these hits represent a different person. Some true believers may return to their favorite sites many times in any given day, with each visit recorded as a separate hit. Moreover, some of those hits represent people like you, who check on these sites to monitor them (not as supporters of their ideology). I'm willing to concede that most visitors are not social scientists doing research; but the fact remains that we do not know the number of visitors from the number of hits, nor do we know why they visit the sites. 
We need to distinguish between legal, moral and social responsibility. Legal responsibility refers to addressing the issue by agencies of state power. In moral responsibility, the personal responsibility of the agent to conscience is at issue, with appeals to moral consideration. Social responsibility relates to the societal implications of a given conduct.

Aristotle was the first to construct a theory of moral responsibility. In discussing

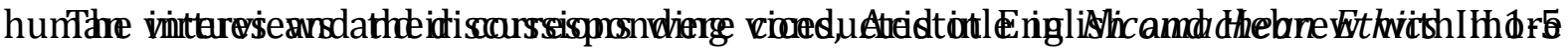

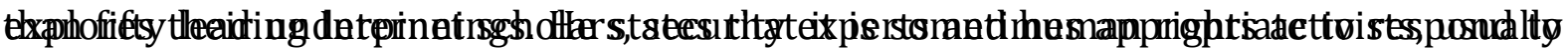

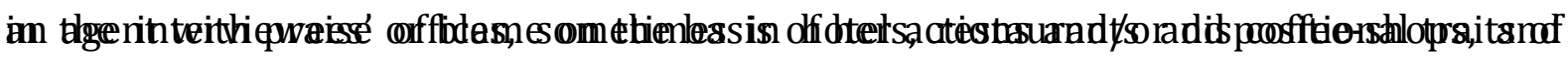

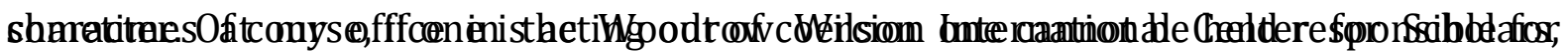

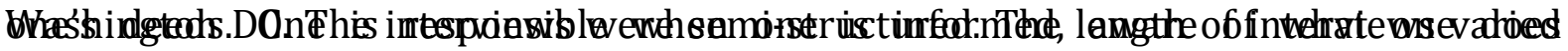

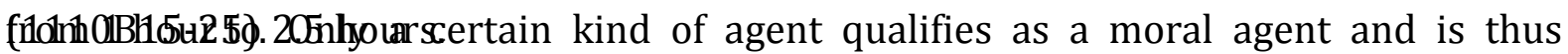
properly subject to ascriptions of responsibility, namely, one who possess a capacity for After transcribing the interviews I sent them for verification and authorization. decision. For Aristotle, a decision is a particular kind of desire resulting from free Some of the security experts did not wish to be attributed. Their wish, of course, is deliberation, one that expresses the agent's conception of what is good. Choice is respected. I retain all files with me.

important, to have desirable ends and relevant means to pursue the end (1111b15-

1113b22). Aristotle spells out the conditions under which it is appropriate to hold a II. Moral and Social Responsibility

moral agent blameworthy or praiseworthy for some particular action or trait. He proposes that one is an apt candidate for praise or blame if and only if the action and/or disposition is voluntary. A voluntary action or trait has two distinctive features: the action or trait must have its origin in the agent. That is, it must be up to the agent whether to perform that action or possess the trait - it cannot be compelled externally. 
And the agent must be aware of what it is she is doing or bringing about (1110a$1111 \mathrm{~b} 4) .^{7}$

Thus, by moral responsibility it is meant that autonomous agents have the understanding of the options before them, have access to evidence required for making judgments about the benefits and hazards of each option, and able to weigh the relative value of the consequences of their choice.

The accompanying concept of social responsibility refers to the responsibility of individuals, groups, corporations and governments to society. People are not islands to themselves. We live within a community and have some responsibilities to it. The responsibilities are positive and negative. That is, we have a responsibility to better the society in which we live, and a responsibility to refrain from acting in a way that knowingly might harm our community. Of course, there are many ways to better society but the responsibility is always ethical in nature. The assumption is that we are rewarded by the social framework in which we live, we care about society, would like to maintain it and to contribute to it. The contribution is proactive. We take active steps to do good and to avoid harm. ${ }^{8}$

\footnotetext{
7 Aristotle, Nicomachean Ethics (Indianapolis: Bobbs-Merrill, 1962). For further discussion, see Susan Sauve Meyer, Aristotle on Moral Responsibility: character and cause (Oxford: Blackwell, 1993); "Moral Responsibility," Stanford Encyclopedia of Philosophy (2004), at http://plato.stanford.edu/

${ }^{8}$ Burton S. Kaliski (Ed.), Encyclopedia of Business and Finance (New York: Macmillan, 2001); Marvin L. Marshall, "Ensuring Social Responsibility," Thrust for Educational Leadership, Vol. 23, No. 4 (1994): 42-43; Clifford Christians and Kaarle Nordenstreng, "Social Responsibility Worldwide," Journal of Mass Media Ethics, Vol. 19, No. 1 (2004): 3-28; Kristie Bunton, "Social Responsibility in Covering Community: A Narrative Case Study," Journal of Mass Media Ethics, Vol. 13, No. 4 (1998): 232-246.
} 
public sector are morally accountable. As Novak, Trevino and Nelson argued, adopting social responsibility norms is the right way to behave. ${ }^{9}$

\section{Hate on the Net}

The story of hate on the World Wide Web began on January 11, 1995 when Don Black established his Stormfront site. ${ }^{10}$ Leaders such as David Duke and Don Black have vainly tried to burnish the reputation of the Klan; to replace the stereotyped image of "ignorant yokels in sheets" with one of scrubbed, educated, articulate, earnest young white men. ${ }^{11}$ Black said: “The Internet is that opportunity we've been looking for ... We never were able to reach the audience that we can now so easily and inexpensively."12

Since its creation, Stormfront has served as a veritable supermarket of online hate, stocking its shelves with many forms of anti-Semitism and racism. In its first two years, Stormfront featured the writings of David Duke, William Pierce of the neo-Nazi National Alliance, representatives of the Holocaust-denying Institute for Historical Review and other assorted extremists. In addition to text articles, early versions of

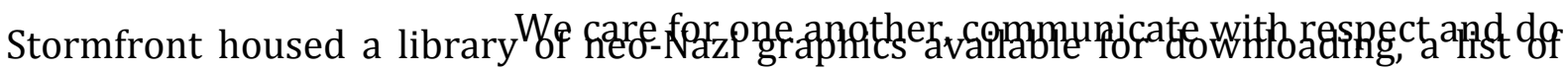
not stand idly by while seeing that others might be in danger. Both the private and the

\footnotetext{
${ }_{9}$ Michael Novak, Business as a Calling: Work and the Examined Life (NY: Free Press, 1996); Linda K. Trevino and Katherine A. Nelson, Managing Business Ethics: Straight Talk about How To Do It Right (NY: John Wiley, 1999).

${ }^{10} \mathrm{http}: / /$ www.stormfront.org.

${ }^{11}$ David S. Hoffman, The Web of Hate: Extremists Exploit the Internet (New York: Anti-Defamation League, 1996), p. 9.

12 Diane Werts, “How the Web Spawns Hate and Violence," Newsday (October 23, 2000 ): B27.
} 
phone numbers for racist computer bulletin boards that were not on the Internet, and a short page of links to other hateful Web sites. ${ }^{13}$

By 1997, Black's site became home to the Web pages of other extremists, such as Aryan Nations and Ed Fields, racist publisher of The Truth At Last, a hate-filled newspaper. In addition to the highly successful Stormfront site which is boasting a traffic rank of 7,495 on the Net (3,270 place in the USA), with 1,686 sites linking in, ${ }^{14}$ Black operates Martinlutherking.org, designed to resemble a documentary-style site, but rather than containing historical information, it instead contains defaming material on the civil-rights leader. Black counts on the fact that of the more than $70 \%$ of schoolaged children and young adults who do research for school papers online, many will not be able to determine the difference between Martinlutherking.org and a legitimate site. ${ }^{15}$ The Afro-Americans are depicted as the enemy. They are brutal, primitive, biologically inferior whose presence represents a corrosive element for the whole American society. In Africa, they were eating one another. They bring their jungle culture to America. They are referred to as niggers, "mud people," source of social pollution and cultural decadence which clashes with the ethnic, civil and economic superiority of the whites. In 2006, there were twenty eight anti-Blacks hate groups, with 820 bloggers, on one blog hosting site, Xanga. ${ }^{16}$

\footnotetext{
${ }^{13}$ Jordan Kessler, Poisoning the Web: Hatred Online (New York: Anti-Defamation League, 1999), p. 4.

${ }^{14}$ http://www.alexa.com/siteinfo/stormfront.org

15 Madeleine Gruen, "White Ethnonationalist and Political Islamist Methods of Fund-raising and Propaganda on the Internet," in Rohan Gunaratna (ed.), The Changing Face of Terrorism (Singapore: Marshall Cavendish, 2004), p. 132.

${ }^{16}$ Michael Chau and Jennifer Xu, "Mining Communities and their Relationships in Blogs: A Study of Online Hate Group," pp. 57-70.
} 
Many of the hate sites are very religious in nature. Religion is perceived as the rock around which life should be organized. Religion provides the answer, indeed the only answer. The argument is that we have little choice in making decisions as everything has already been decided for us by God. People cannot base anything outside their ultimate commitment to their faith. After all, it is far better to trust the consistent and enlightened almighty who knows all than to trust reason of fallible humans.

Some of the anti-Black sites are also anti-immigration (especially Latino), and anti-Muslim. ${ }^{17}$ Minorities endanger the position of whites in the United States. They increase their numbers by tempting white women. Indeed, interracial marriage is one of the ideas, and some claim the idea that most upsets racists on the Internet and is likely to drive them too advocate anti-Black hate crime. A reiterated theme is the need to secure white supremacy in the United States now for "our people" and for the coming generations, "a future for White children." 18

A second hated group on the Net is the homosexuals. They are portrayed as seeking to sexually ensnare young white males. Gay behaviour is perceived by bigots as contradictory to nature, perverted, sinful, morally abominable, threatens to undermine the religious values of the white community. Homosexuals do not reproduce and thus threaten the survival of their own race. Furthermore, they spread contagious and deadly diseases and are no less than angles of death. They should be hunted down in the same way witches were once hunted in Europe. ${ }^{19}$

\footnotetext{
17 American Renaissance, http://www.amren.com/index.html; Jewish Task Force, http://www.jtf.org/

18 Jack Glaser, Jay Dixit, and Donald P. Green, “Studying Hate Crime with the Internet: What Makes Racists Advocate Racial Violence?," Journal of Social Issues, Vol. 58, No. 1 (2002): 188.

${ }^{19}$ http://www.anti-gay.com; see also Antonio Roversi, Hate on the Net (Aldershot: Ashgate, 2008), p. 94.
} 
Many racist, White Power Web sites contain anti-gay propaganda (e.g. Stormfront), but some Web pages focus their hatred primarily on gays and lesbians. Perhaps the most vile and best-known anti-gay Web site is God Hates Fags, ${ }^{20}$ which is maintained by Benjamin Phelps, grandson and compatriot of Westboro Baptist Church (WBC) leader Fred Phelps. ${ }^{21}$ Other notorious sites are Forerunner international: Homosexuality, ${ }^{22}$ Traditional Values Coalition, ${ }^{23}$ and Exodus International. ${ }^{24}$

The third most hated group is the conspirators, i.e. the Jews. The Jews are situated in power positions in society. The Jews are united by a secret pact to set in motion a global conspiracy to rule the world. The Jews lie in order to achieve this aim and are successful in brainwashing the minds of Christian-Americans. They control the academia, the media, the banks, MTV, the feminists. There are sites to educate you how Jews look like, their power, how they control America and the world (ZOG=Zionist Occupied Government). ${ }^{25}$ The Creativity Movement explains that "CREATIVITY is a religion for the survival of the White Race. Time is running out. The time for action is NOW! The jew is the master of perversion. When Creativity triumphs the White Race

\footnotetext{
${ }^{20} \mathrm{http}: / /$ www.godhatesfags.com/

${ }^{21} \mathrm{http}: / /$ www.godhatesfags.com/index.html.

22 http://forerunner.com/forerunner/X0227.html

${ }^{23} \mathrm{http}: / /$ www.traditionalvalues.org/

24

http://www.exodusinternational.org/.

See

also

http://www.defendthefamily.com/pfrc/books/sevensteps/Epilogue/index.html

25 http://www.jewwatch.com/; http://jewishfaces.org/; http://www.faem.com/; 1001 Quotes By and About Jews, http://www.stormfront.org/posterity/index.html; http://jewishtribalreview.org/; http://www.kriegsberichter.com/
} 
will be jew-proof for all time. White Men of the World, UNITE! You have nothing to lose but jewish tyranny" (sic.).26

Anti-Semitic sites include African-American literature about the so-called "Secret Relationships between Jews and Blacks" which essentially describe as Jews have exploited black people throughout the ages. ${ }^{27}$ Many anti-Semitic sites contain antiIsraeli/anti-Zionist propaganda. ${ }^{28}$ Some Anti-Semitic sites promote exclusion of the Jewish people and deny the Holocaust. ${ }^{29}$ Some combine Jewish hatred, Holocaust denial, Jewish/Israeli conspiracies and revisionist history. ${ }^{30}$ Extensive documentation, including free downloads of videos, is offered to support all this "unrefuted truth." Among the most visited sites promoting Holocaust denial are the Institute for Historical Review, originally established for this purpose, ${ }^{31}$ Historical Review Press, ${ }^{32}$ Bradley Smith and his Committee for Open Debate of the Holocaust (focusing largely on U.S.

${ }^{26}$ http://creativitynsw.com/

${ }^{27}$ Nation of Islam, The Secret Relationship between Blacks and Jews (Chicago, Illinois, October 16, 1991), http://www.mailstar.net/secret.html. See also http://www.blacksandjews.com/Welcome.html; http://iamthewitness.com/doc/The.Secret.Relationship.Between.Blacks.and.Jews.htm

http://holywar.org/;

http://www.stormfront.org/posterity/ci/smith6.html; http://www.davidduke.com/, http://www.duke.org/, http://www.whitecivilrights.com and http://www.davidduke.org/; http://finalconflictblog.blogspot.com/; http://www.nazi.org/; http://www.palestine-info.co.uk/en/; http://www.nacazai.org/; Revolution Muslim, http://www.revolutionmuslim.com/

${ }^{29}$ http://www.air-photo.com/; http://www.air-photo.org/

$30 \quad$ http://holywar.org/; http://www.jewwatch.com/; http://www.fathersmanifesto.net/wtc.htm; http://www.whitecivilrights.com/?p=1929

${ }^{31}$ http://www.ihr.org/.

32 http://www.ety.com/HRP/revisionholocaust/holocaustindex.htm 
college campuses), ${ }^{33}$ and sites sponsored by Arthur R. Butz, ${ }^{34}$ David Irving, ${ }^{35}$ Ahmed Rami, ${ }^{36}$ and Ernst Zündel. ${ }^{37}$ All portray themselves as gutsy political libertarians who develop hubs, even paradigms, of unbiased, unorthodox historical research. One site conveniently assembles information about all revisionist "scholars." It explains "All productive and worthwhile historical writing is 'revisionist' in the sense that it takes into account newly available historical evidence and new insights and perspectives." 38

The elaborate hate sites hate all of the above: African-Americans and non-white immigrants, Muslims, Jews and gays. They are quite eclectic, offering wide racial publications. ${ }^{39}$ Some of them publish in a number of languages. Stormfront contains discussions in many European languages. ${ }^{40}$ www.natvan.com of the National Alliance is being published in sixteen languages. Extensive websites contain documents, journals, newspapers, videos, radio, TV shows, books, games, survival information,

\footnotetext{
${ }^{33}$ http://www.codoh.com/.

${ }^{34}$ http://www.codoh.com/butz/; http://www.revisionists.com/revisionists/butz.html.

$35 \quad$ http://www.fpp.co.uk/; $\quad$ www.fpp.co.uk/online/index.html
}

http://news.bbc.co.uk/1/hi/uk/4449948.stm .

36 http://radioislam.org/islam/english/toread/jewslave.htm; http://radioislam.org/adl/net.htm; http://www.adl.org/poisoning_web/rami.asp.

${ }^{37}$ http://www.zundelsite.org/ .

38 www.Revisionists.com. See also http://vho.org/aaargh/engl/engl.html; http://www.adelaideinstitute.org/; http://www.toben.biz/;

http://www.air-photo.com/english/; http://www.air-photo.org/index.php; http://www.holocaustdenialvideos.com; http://www.landoverbaptist.net/showthread.php?t=9197; http://www.holocaustdenialvideos.com/; http://www.goodnewsaboutgod.com/studies/spiritual/home_study/holocaust_lie.htm

${ }^{39}$ http://www.racerealist.com/1b.htm

${ }^{40} \mathrm{http}: / /$ www.stormfront.org/forum/ 
homeschooling information, cartoons, artwork, jokes, quotes, poems, free stickers and merchandise. In addition, there are also anti-religious sites, ${ }^{41}$ anti-abortion, ${ }^{42}$ antiliberal, anti-Communist and anti-feminist sites. ${ }^{43}$

\section{Countering Hate}

In the following discussion I wish to outline all that can be done to encounter Nethate. One standard is not enough. Instead, we need to resort to a combined action that would provide ample socially-responsible answer to the challenges we face.

41 For sites attacking all religions, see http://exposingsatanism.org/index1.htm; http://truthandgrace.com/; http://peace-of-mind.net/; http://www.odinist.com/. For anti-Christianity sites, see http://www.anus.com/altar/index.html; http://www.jcnot4me.com/. For anti-Islam sites, see http://www.glistrup.nu/forum/forum.cfm; http://truthandgrace.com/ISLAM.htm. For anti-Hinduism sites, see JESUS-IS-LORD.COM; http://www.mostholyfamilymonastery.com/H.O.W._of_JP2_and_V2sect_regarding_pagans_and_infidels.ht ml; http://peace-of-mind.net/; http://truthandgrace.com/Hindu.htm; Hindu American Foundation, Hyperlink to Hinduphobia (2007), at http://www.hafsite.org/.

42 http://www.tcrp.us/; http://www.armyofgod.com/; http://dspace.dial.pipex.com/finalconflict/a146.html. Until it was shut down, the Nuremberg Files website instigated violence against abortionists. See Planned Parenthood of the Columbia/Willamette Inc. et al v. American Coalition of Life Activists, U.S Court of Appeals for the Nine Circuit (May 21, 2002); Planned Parenthood of the Columbia/Willamette Inc. et al v. American Coalition of Life Activists, No. 95-1671-J0, 41 F.Supp.2d 1130 (March 16, 1999); Planned Parenthood of the Columbia/Willamette Inc. et al v. American Coalition of Life Activists, U.S Court of Appeals for the Nine Circuit (March 28, 2001). However, the same information can be found at present at another site, http://www.christiangallery.com/atrocity/aborts.html

${ }^{43}$ See Richard Delgado and Jean Stefancic, Understanding Words That Wound (Boulder, CO: Westview, 2004), p. 125. 
Speech v. Speech - This is the preferred strategy advocated by many (especially American) Internet experts and human rights activists who argue that the way to tackle hate on the Net is by more communication, by openness and by exposing the problem. ${ }^{44}$ We need to show that all human beings deserve respect and concern, all have dignity, and that a racially based society negates liberal-democratic values that we all hold dear: Pluralism, diversity, individuality, liberty, equality, tolerance, justice. The AntiDefamation League of B'nai Brith has a web site about combating anti-Semitism. ${ }^{45}$ Another example is the Nizkor project led by Ken McVay designed to combat Holocaust denial. $^{46}$ It is possible to set up a listserv to provide information and analyses to interested parties. Sending newsletters to subscribers, and posting informational web sites, are initiatives anyone can undertake.

However, countering hate speech with more speech is not enough. It is irresponsible to assume it can be enough. Nethate is concrete, tangible and harmful. Allowing hatemongers and racists to release their pent-up emotions in the form of speech, countering this with speech and thinking that this would not result in violence and that their targets will be much safer, ignores reality. ${ }^{47}$ Far more should be done.

Education -- As previously stated, we have a responsibility to better our society. Caring for one another, doing good and avoiding harm entails activity at primary and high schools designed to alert about hate on the Internet, its forms and attractions (music, video games, activities for kids); why racism is logically incoherent, empirically

\footnotetext{
${ }^{44}$ Interviews with dozens of activists, Washington DC (September 2007-July 2008).

45 http://www.adl.org

${ }^{46}$ http://nizkor.almanac.bc.ca

47 R. Cohen-Almagor, “Countering Hate on the Internet - A Rejoinder," Amsterdam Law Forum, Vol. 2, No. 2
} (2010): 125-132. 
unattainable, anti-democratic and inhumane; why it is harmful; who is targeted. The education programme should reflect on the history of hate and the connection between hate and some of the most horrific human catastrophes men inflicted upon other men (Yugoslavia, Rwanda). Here I commend the work of Partners Against Hate, ${ }^{48}$ Family Online Safety Institute, ${ }^{49}$ and Enough is Enough. ${ }^{50}$ AOL was a party to another initiative called Take25, initiated by the National Center for Missing \& Exploited Children. The goal of Take 25 is to heighten awareness about children's safety issues. With a focus on prevention, the campaign encourages parents, guardians, and other trusted-adult role models to spend time talking to kids and teaching them ways to be safer. ${ }^{51}$

In Britain, the government published in June 2008 a toolkit guidance titled Learning Together to Be Safe on preventing violent extremism. The toolkit emphasises the importance of working with children and young people and encouraged local partnerships to engage with schools and colleges. It is designed to raise awareness amongst schools of the threat from violent extremist groups and the risks for young people; provide information about what can cause violent extremism, about preventative actions taking place locally and nationally and about where schools can get additional information and advice; provide advice on managing risks and responding to incidents locally, nationally or internationally that might have an impact on the school community; help schools understand the positive contribution they can make to empowering young people to create communities that are more resilient to

48 http://www.partnersagainsthate.org/about_pah/index.html; Partners Against Hate et al., Investigating Hate Crimes on the Internet (Washington DC., September 2003).

49 http://www.fosi.org/cms

50 http://www.internetsafety101.org/dangers.htm.

51 http://www.take25.org/page.asp?page $=47$ 
extremism, and protecting the wellbeing of particular pupils or groups who may be vulnerable to being drawn into violent extremist activity. ${ }^{52}$

In Australia, the B'nai B'rith Anti-Defamation Commission launched program called "Click Against Hate." It is a program for Jewish day schools on identifying and responding to anti-Semitism online. ${ }^{53}$

Hate watch -- The idea is to comprise a list of hate sites. The list needs to be constantly updated and can have various functions: Alert people about the sites; included in blocking programmes; sent to indexed search engines so that hate site can be properly labelled; they can be sent to access providers as part of a campaign to have the sites shut down.

At present, a number of sites exist to monitor and document hate literature on the Internet. Some notable examples are B'nai Brith Canada's League for Human Rights, which hosts a hate hotline ${ }^{54}$; Hate Watch of the Southern Poverty Law Center, ${ }^{55}$ and the Simon Wiesenthal Center, which has identified thousands of offensive Web sites. ${ }^{56}$ Wiesenthal's annual CD, Digital Hate, lists sites that promote antisocial and illegal activities ranging from hate music to suicide bombing.

52 Teachernet, Preventing violent extremism, http://www.teachernet.gov.uk/wholeschool/violentextremism/. For a Canadian perspective, see Anne Taylor, “Helping Kids Deal with Online Hate,” School Libraries in Canada, Vol. 25 Issue 4 (2006): 14-16.

53 http://www.antidef.org.au/www/309/1001127/displayarticle/click-against-hate--1011350.html; Discussions with Australian Internet experts and human rights activists, Jerusalem (December 16-18, 2009).

54 http://www.bnaibrith.ca/league/league.htm

55 http://www.splcenter.org/blog/?source=redirect\&url=hatewatch.org

56 http://www.wiesenthal.com/site/pp.asp?c=lsKWLbPJLnF\&b=4441251 
Citizens' initiatives to combat hate - Aristotle teaches us that it is appropriate to respond to agents on the basis of their actions. One example is "Coloradans United Against Hatred" (CUAH). This is a non-profit organization dedicated to eliminating the damage caused by hate groups. It focuses on hate group activity within the state of Colorado. Its board includes members of the Jewish, Black, Moslem, Hispanic, gay, and other communities affected by the actions of hate groups. Its mission states that it is intended to provide a medium to educate people as to the effects of hate group activity; to provide funds or other assistance to help the victims of hate crimes and assist in fighting the hate groups, and to provide information so that the public can take action against hate groups of their own. ${ }^{57}$

Another initiative is LAMBDA which focuses on support, education, and advocacy through organization of the gay, lesbian, bisexual and transgender (GLBT) community to provide a source for accurate information about and within their community. It aims to improve the public's awareness and understanding of the GLBT community by providing technical assistance, seminars, workshops, and public education campaigns. LAMBDA wishes to create change through the empowerment of GLBT, the fighting of homophobia, prejudice and ignorance, and the expansion of understanding of sexual orientation and related issues. ${ }^{58}$

Filters -- Filtering, monitoring, and auditing tools are generally divided into two categories: client-side and server-side. Client-side software is installed locally on the user's computer and is maintained by the user. Its effectiveness is dependent on the

\footnotetext{
57 http://www.cuah.com/index.htm

58 http://www.lambda.org/
} 
user's installation, configuration, regular maintenance, and use of the software. Clientside filtering tools are very popular and have been deployed for over a decade. They are relatively straightforward to implement and offer parents and guardians an easy way to provide a safer Internet environment. In the server-side approaches filtering of inappropriate content is performed before the content reaches a user's computer and is bounded by the standards of the website or service platform itself. Server-side filtering is often used to refer to content filtering at the ISP level. ${ }^{59}$ ISPs can block access to all websites associated with a blacklisted IP address or filter content that matches a list of blacklisted keywords.

Filters can be installed at institutions (schools, universities, work places) and at homes. Ideally, human rights organizations should sponsor these filters so people won't be reluctant to use them only because of the cost involved. Among the growing number of fairly effective filtering devices are NetNanny, SurfWatch CyberPatrol, and HateFilter. These empower parents and employers wanting to prevent children and employees from browsing Internet sites with objectionable messages. The software functions by scanning Web pages for specific words or graphic designs and then restricting user access to them. For example, HateFilter, developed by the Anti-Defamation League, specifically targets several hundred sites that have already been identified as hate sites. When it is activated, the HateFilter denies access to Internet sites advocating hatred, bigotry or violence against Jews, minorities and homosexuals. 60

\footnotetext{
${ }^{59}$ Final Report of the Internet Safety Technical Task Force, Enhancing Child Safety and Online Technologies (Boston, Mass.: Berkman Center for Internet and Society, 2008), Appendix D; interviews with Internet experts, Washington (May 9-15, 2008).

${ }^{60}$ Interview with Brian Marcus, former Director of ADL Internet Monitoring, Washington (June 5, 2008).
} 
A more refined method is proxy filtering. Proxy servers which produce local copies of popular websites and are commonly deployed by ISPs to save bandwidth, can be used to decide whether to allow requests for individual webpages. This avoids overblocking, but can be very expensive. If the system were to be rolled out across entire networks and ISPs failed to make substantial investments in the required hardware, it could slow down Internet traffic substantially. Hybrid IP and proxy filtering is a practical response to the relative expense of proxy filtering and the significant overblocking which results from IP filtering. In the first instance, this system checks against a list of IP addresses, but does not block them immediately. Instead, all requests for "problematic" IP addresses are channelled to a proxy server which inspects them for individual webpages and blocks them if required. The initial layer makes it possible for the vast majority of internet traffic to proceed without a full inspection, thus reducing the expense of straight proxy filtering, whilst the second layer helps to minimise the problems of overblocking. Hybrid IP and proxy filtering is the basis for the British Telecom Cleanfeed system for blocking child sexual abuse content. It seems to resolve the trade-off between cost and accuracy: it is neither too crude nor is it excessively expensive. Yet, like all other methods of filtering, it fails to capture dynamic content (for example, chat and instant messaging) and relies on blacklists of banned webpages, which raises all kinds of political questions. ${ }^{61}$

61 Tim Stevens and Peter R. Neumann, Countering Online Radicalisation: A Strategy for Action (London: The International Centre for the Study of Radicalisation and Political Violence and The Community Security Trust, 2009), p. 18. For further discussion, see Ronald Deibert, John Palfrey, Rafal Rohozinski and Jonathan Zittrain (eds.), Access Denied: The Practice and Policy of Global Internet Filtering (Cambridge, MA \& London: MIT Press, 2008). 
context where they were uttered. Thus, for instance, sites like Nizkor that frequently cite anti-Semitic materials in order to refute them will not be censored. Then human eye overseas those statements that were flagged out and filter out hate. Undoubtedly, there will be more filtering inventions as technology progresses in attempt to find the optimal solution that would block only the targeted information, no less and no more.

Install computer blocking programs at work and school -- Governments at all levels employ between $30 \%$ and $60 \%$ of the work force. Public schools attract an even higher percentage of the school age population. It should be a matter of government policy that all government employees should not access hate web sites, unless the access is related to their work. Generally speaking, workers have no business with hate sites. As aforesaid, both the private and the public sector should adopt social responsibility norms. It should be an education policy that students, at least students at public schools, should not access hate sites unless it is directly related to their studies. Employees and students should never send hate e-mails, harassing others with their hatred.

An insistence by employers and schools that employees and students not access hate sites during work and school would have a dramatic impact on the penetration of these sites. The mere statement of a hate site no access policy and no hate e-mail policy would be a stance against the promotion of hatred. ${ }^{62}$ The purpose of this measure is

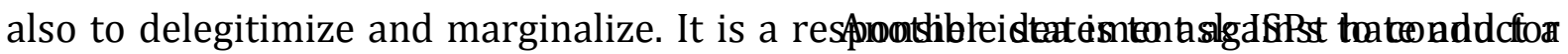
burmadie rdigroityitoring. First, look for a string of keywords. Then checking them in the ISPS' responsibility - ISPs and web-hosting companies should develop standards for responsible and acceptable practices for Net users. IPSs' terms of service usually grant

62 David Matas, "Combating hate on the internet without recourse to law," Panel contribution for the INACH Conference 2009 "Freedom of Speech versus Hate Speech" (November 9, 2009, Amsterdam, The Netherlands). Discussion with Matas, Jerusalem (December 17, 2009). 
ISPs with the unilateral right and ability to block service to those who violate the terms. ISPs are reluctant to do this as they wish to maintain business. They are for profit. However, there were instances in which ISPs denied service, commonly due to violation of copyrights. When someone complains about copyright violation, the ISP will take the material off the server. ISPs are inclined to abide by such requests. ${ }^{63}$

Quite a few ISPs, web-hosting companies and social networks also bar blatant expressions of bigotry, racism and/or hate. ${ }^{64}$ Judicial-Inc declares itself to be a ProChristian website with approximately 110,000 monthly readers. In effect, it is an antiSemitic site of the worse kind. All of Judicial's 4,200 web pages were hosted by Godaddy.com, and the company decided to suspend the Judicial account, apparently with zero notice. ${ }^{65}$ Zionist watch, another anti-Semitic site, was hosted by WordPress until it was suspended for a violation of the company's terms of service which expressly prohibit hate content. ${ }^{66}$ Yahoo! prohibits uploading, posting or otherwise transmitting harmful, threatening, hateful, or racially, ethnically or otherwise objectionable content. ${ }^{67}$ Facebook, the largest social networking site with more than 250 million users, prohibits posting content that is hateful or threatening. ${ }^{68}$

63 Interview with Dr. Herb Lin, National Academy of Sciences, Washington DC (May 15, 2008). See R. Cohen-Almagor, "Responsibility of and Trust in ISPs," Knowledge, Technology and Policy (forthcoming).

http://www.elluminate.com/license_agreement.jsp ;

Evehosting.co.uk; http://host2host.com/contract.htm; http://www.nyophosting.com/.

65 http://judicial-inc.biz/1_master_supreme.htm

${ }^{66}$ http://zionistwatch.wordpress.com/; http://en.wordpress.com/tos/

${ }^{67}$ http://info.yahoo.com/legal/us/yahoo/geocities/gctos/

${ }^{68}$ http://www.facebook.com/terms.php?ref=pf 
Francisco, California, bans "hate propaganda" and "hate mongering." 69 Fortunecity requires its users to agree to "not upload, post, email, transmit or otherwise make available (collectively, 'Transmit') any Content that is unlawful, harmful, threatening, abusive, harassing, tortuous, defamatory, vulgar, obscene, libelous, invasive of another's privacy, hateful, or racially, ethnically or otherwise objectionable."70 However, having codes without adhering and enforcing them is meaningless. These responsible codes should be steadfast. ISPs, web-hosting companies and social networks are expected to abide by their own terms of conduct.

This is stressed because Facebook, for instance, hosts the National Association for the Advancement of White People. ${ }^{71}$ Conduct a simple search on Facebook: "Holocaust denial" and you will get some results, among them two "Holocaust denial" groups, and one "Against Holocaust Denial Laws."

Net users' initiatives against hate -- Forums to discuss the hate challenge and how to address it. For instance, Facebook hosts different such groups, among them are United Against Hatred ${ }^{72}$ and United Against Hate. ${ }^{73}$ There should be Net users' forums insisting that each ISP will have a code of responsible conduct which includes an anti-hate XOOM.com of San provision, and that ISPs enforce and abide by their own code of conduct.

ISPs proactive steps -- Anti-hate speech advocates should explain to ISPs managers the nature of the contested hate, its potential harms, and why corporate responsibility to the community means taking the content off their servers. This may lead to ISPs

\footnotetext{
${ }^{69}$ ADL, Combating Extremism in Cyberspace (2000): 11.

70 https://secure.fortunecity.com/order/register/agreement.php?siteid=55527

71 http://www.facebook.com/group.php?gid=2255936485

72 http://www.facebook.com/topic.php?uid=58653965167\&topic=7617

${ }^{73} \mathrm{http}: / /$ www.facebook.com/group.php?gid=230091163153\&ref=ts
} 
taking proactive steps to prevent the presence of hate sites on their servers. That means, not only taking action after being alerted but taking active steps to block and eliminate such sites. As Aristotle claimed, choice is important, to make the right decision in pursuing desirable ends via appropriate just means. By "just" Aristotle meant conducive to the well-being of the community in which we live. Whatever responsible steps that corporations take to promote Net security, it is imperative that these steps should be transparent, clear, known and reasoned to the public.

Some ISPs reveal a sense of responsibility. Being aware of the harms of such hate sites they remove the sites from their server. An example of cooperation between an Internet monitoring organization and an ISP concerns the Anti-Defamation league (ADL). Brian Marcus who headed their Internet division said that private companies may decide not to post messages containing hate speech because this might be bad for their business. The ADL approached a CEO of a web hosting company in Texas, asking him where he would draw the line between legitimate and illegitimate speech. He answered that hate is protected speech, but threats are not. Marcus indicated that one of the sites he hosted claimed all members of minorities should be hanged from street lamps. The CEO was surprised. For him, this was a threat. This is not a threat according to the American law, ${ }^{74}$ but for this $\mathrm{CEO}$ it was too much. Marcus then showed him some

\footnotetext{
${ }^{74}$ Anna S. Andrews, "When is a Threat 'Truly' a Threat Lacking First Amendment Protection? A Proposed True Threats Test to Safeguard Free Speech Rights in the Age of the Internet," The UCLA Online Institute for Cyberspace Law and Policy (May 1999), at http://www.gseis.ucla.edu/iclp/aandrews2.htm; see also Raphael Cohen-Almagor, The Scope of Tolerance: Studies on the Costs of Free Expression and Freedom of the Press (London: Routledge, 2006): 256-258.
} 
150 such sites. After deliberation, the company had closed some $110-120$ of the problematic sites. ${ }^{75}$

In December 2008, YouTube contacted the Anti-Defamation League for its expertise in dealing with Nethate. In one outgrowth of that partnership, the League is now a contributor to YouTube's newly launched Abuse and Safety Center, where users are empowered to identify and confront hate, and to report abuses. The YouTube Abuse \& Safety Center features information and links to resources developed by ADL to help Internet users respond to and report offensive material and extremist content that violates YouTube's Community Guidelines on hate speech. ${ }^{76}$ However, you will still find quite a few questionable video clips on YouTube. ${ }^{77}$

Like ISPs, connectivity providers that supply ISPs and Domain Name Registrars should insist as a condition for the provision of their service, that it won't be used for

75 Interview with Brian Marcus, former ADL Director of Internet Monitoring, Washington DC (April 16, 2008).

76 http://help.youtube.com/support/youtube/bin/answer.py?hl=en_uk\&answer=126264; http://help.youtube.com:80/support/youtube/bin/request.py?contact_type=abuse; "YouTube Taps ADL As Partner In Fight Against Hate," at http://www.adl.org/PresRele/Internet_75/5416_75.htm

http://www.youtube.com/watch?v=Y0UuqFaoMiM\&NR=1;

http://www.youtube.com/watch?v=lzE5Z3SZ1Jg; http://www.youtube.com/watch?v=HI4b2zYA9vE; http://www.youtube.com/watch?v=Fu3XvQv_IXE;

http://www.youtube.com/watch?v=mNtgxJdo9ds\&feature=PlayList\&p=1AFED9C2D71B446B\&index=3;

http://www.youtube.com/watch?v=dBhFgnADkpY\&NR=1;

http://www.youtube.com/watch?v=dw20MnHFCwI\&feature=PlayList\&p=1AFED9C2D71B446B\&index= 
the promotion of hate. Every access provider should insert into its subscription contract an anti-hate provision.

Pressuring ISPs to remove hate sites -- There have been attempts by the Simon Wiesenthal Center and the ADL to convince ISPs to remove objectionable web sites from their servers. Sometimes this effort succeeded and sometimes not. Given the expansive and international nature of the Net, sites can easily migrate from one ISP to another. Pressuring ISPs has come under criticism by civil liberties groups. While approving of the Wiesenthal Center's campaign to expose hate group sites, the American Civil Liberties Union has criticized their attempts to pressure ISPs. ${ }^{78}$ Civil liberties organizations equate tolerance with free expression, but even they recognize that free speech has limits. They do not countenance fraud, criminal conspiracy, libel, and child pornography. ${ }^{79}$

What ISPs and hosting companies could certainly do is to provide a uniform channel for user complaints. Such a channel (which could be as simple as a link to the CyberTipline) could easily be placed on the complaints or customer service page of the service provider. ${ }^{80}$

Omit or at least label hate websites from search engines -- In 2002, Google, the world's most popular search engine, has quietly deleted more than 100 controversial sites from some search result listings. However, it did it secretly, without public discussion or explanation and, as a result, was subjected to incisive criticism. Most of the sites that were removed from Google.fr (France) and Google.de (Germany) were

\footnotetext{
${ }^{78}$ David Resnick, "Tolerance and the Internet," in Gerson Moreno-Riano (ed.), Tolerance in the Twentyfirst Century: prospects and challenges (Lanham, MD.: Lexington Books, 2006), p. 218.

${ }^{79}$ Ibid.

80 Dick Thornburgh and Herbert S. Lin (eds.), Youth, Pornography, and the Internet (Washington, DC: National Academy Press, 2002): 380; interview with Herb Lin, Washington DC (May 15, 2008).
} 
anti-Semitic, pro-Nazi or related to white supremacy. ${ }^{81}$ The removed sites continue to appear in listings on the main Google.com site.

Labelling, naming and shaming -- ISPs and Web-hosting services that refuse to cooperate and continue to provide platform for hate may be named and shamed. In England, the culture minister, Barbara Follett, and her Tory shadow, Ed Vaizey, have backed the idea that web providers must be embarrassed into dealing with violent, sexually explicit web content. ${ }^{82}$ Same can be proposed about hate. Web-hosting companies that are friendly to racial propaganda should be named and shamed. The present host of Stormfront is a Texan company called The Planet that has very lose Terms of Service that would allow anything that is legal. ${ }^{83}$ The First Amendment and profit conveniently go hand in hand. Social responsibility and respect for people are secondary.

Business ban -- If all the above does not help, human rights organizations should call to ban services of hateful ISPs. If ISPs fear that they might lose business, they may change their mind and assume responsibility.

International cooperation - The Internet is international in scope and therefore combating Nethate requires global cooperation. In 1996, a governmental organization in Germany, Jugendschutz.net, and a Nongovernmental organization in the Netherlands, Stichting Magenta, Meldpunt Discriminatie Internet, were the first organizations in the

\footnotetext{
${ }^{81}$ Declan McCullagh, "Google excluding controversial sites," CNET News (October 23, 2002).

82 Patrick Wintour, "Web providers to be named and shamed over offensive content," The Guardian (November 15, 2008).

$83 \mathrm{http}: / /$ content.theplanet.com/Documents/legal/Planet-TOS.pdf. Senior ADL directors spoke with the owner of The Planet. To no avail. They said it was a waste of time. Discussion with senior ADL directors, New York (March 22, 2010).
} 
world to start a dedicated outfit to address the problems of racism, anti-Semitism, hate against Muslims, gays, and other discrimination or incitement to hatred, each in their own country. In 2002, they founded the International Network Against Cyber Hate (INACH). The vision of INACH is to act collectively against discrimination, promoting respect, citizenship and responsibility, enabling Internet users to exercise their right of freedom of speech with respect for the rights and reputations of others. Netusers should be able to freely use the Internet without experiencing cyber hate. ${ }^{84}$ INACH monitors the Internet and publishes overviews and reports about the situation in different countries. Today, the network consists of eighteen organizations in Europe and North America. INACH acts as an umbrella organization for hotlines specializing in racist and hateful content.

Publishing overviews and reports on a regular basis -- publishing names of hate sites, highlights of their content, their locations, their ISPs, both successful and unsuccessful attempts to curtail their activities. One example is Deborah Stone's, of the Australian B'nai B'rith Anti Defamation Commission (Australia), report on antiSemitism on the Internet. 85

Law and adherence to international conventions -- The international community has a responsibility to unite in order to combat anti-social activities. On some global issues there is a need for international cooperation to respond to global concerns. Indeed, the international community has legal, social and moral responsibilities. More and more countries understand the need to cooperate in order to tackle Net abuse. There is more

\footnotetext{
${ }^{84}$ http://www.inach.net/inach-conf-2009-program-public.pdf

85 Deborah Stone, To hate, click here: antisemitism on the internet, Special Report, No. 38 (August 2008), http://www.antidef.org.au/www/309/1001127/displayarticle/adc-news-december-2009-1011568.html or http://www.antidef.org.au/secure/downloadfile.asp?fileid=1010474
} 
awareness of the threats and of the needs in order to provide social security. As the Internet is an international medium, countries realize the urgency for transnational coordination. At present, given the magnitude of anti-social and violent phenomena on the Net, lack of such coordination is simply irresponsible.

One obstacle in the international efforts to fight against hate is that there are different definitions of hate. In Germany, for instance, scientology is considered as a dangerous cult. The German government maintains that Scientology is dangerous for its members and possibly dangerous for society. ${ }^{86}$ In other countries, this is not the case. Having said that, I'd like to highlight international conventions that are pertinent to the fighting against hatred. Former Canadian Minister of Justice, Prof. Irwin Cotler, explained in an interview that international treaties are important because they state that hate speech does not enjoy the protection of free speech; that hate speech is outside the ambit of protected speech..$^{87}$

The Universal Declaration of Human Rights (1948) declares (Article 1): “All human beings are born free and equal in dignity and rights. They are endowed with reason and conscience and should act towards one another in a spirit of brotherhood." It further accentuates (Article 2):

Everyone is entitled to all the rights and freedoms set forth in this Declaration, without distinction of any kind, such as race, colour, sex,

86 Official German responses to Scientology, http://home.snafu.de/tilman/krasel/germany/stat.html; see also http://home.snafu.de/tilman/krasel/germany/; Andrew Purvis, "Germany's Battle Against $\begin{array}{llll}\text { Scientology," } \quad \text { Time } & \text { (December }\end{array}$ http://www.time.com/time/world/article/0,8599,1695514,00.html

87 Interview with Prof. Irwin Cotler, Montreal (July 24, 2002). 
language, religion, political or other opinion, national or social origin, property, birth or other status. Furthermore, no distinction shall be made on the basis of the political, jurisdictional or international status of the country or territory to which a person belongs, whether it be independent, trust, non-self-governing or under any other limitation of sovereignty. 88

The 1966 International Covenant on Civil and Political Rights states that "any advocacy of national, racial or religious hatred that constitutes incitement to discrimination, hostility or violence shall be prohibited by law" (article 20-2).89 Similarly, the U.N. International Convention on the Elimination of all Forms of Racial Discrimination ("ICERD") (1969, Article 4) requires its signatories to outlaw "all dissemination of ideas based on racial superiority or hatred, incitement to racial discrimination," violent acts or incitement to violence against any race or ethnic group, and also "the provision of any assistance to racist activities, including the financing thereof." 90 States Parties condemn all propaganda and all organizations which are based on ideas or theories of superiority of one race or group of persons of one colour or ethnic origin, or which attempt to justify or promote racial hatred and discrimination in any form. ${ }^{91}$

\footnotetext{
88 http://www.un.org/en/documents/udhr/

89 International Covenant on Civil and Political Rights, art. 20-2, 999 UNTS 171, opened for signature December 16, 1966, Article 20(2), http://www2.ohchr.org/english/law/ccpr.htm

${ }^{90}$ International Convention on the Elimination of all Forms of Racial Discrimination, 660 U.N.T.S. 195, art. 4(a), entered into force on January 4, 1969, http://www2.ohchr.org/english/law/cerd.htm 91 International Convention on the Elimination of all Forms of Racial Discrimination, http://www2.ohchr.org/english/law/cerd.htm
} 
In Europe, there are several important documents that should be observed. The European Convention for the Protection of Human Rights and Fundamental Freedoms (1950) holds (Article 10) that the exercise of these freedoms may be subject to such formalities, conditions, restrictions or penalties as are prescribed by law and are necessary in a democratic society, in the interests of public safety, for the prevention of disorder or crime, "for the protection of health or morals, for the protection of the reputation or rights of others...."92 Furthermore, the Convention on the Prevention and Punishment of the Crime of Genocide (1948) requires contracting parties to punish direct and public "incitement to commit genocide." 93

Some European countries are working together to combat cyber crime and cooperate to criminalize acts of racist and xenophobic nature committed through the computer system. ${ }^{94}$ The First Additional Protocol to the Council of Europe's Convention on Cybercrime (2003) stresses that "all human beings are born free and equal in dignity and rights." ${ }^{\prime 95}$ It requires the adoption of measures prohibiting the transmission of racist or xenophobic messages through computer systems. It criminalizes Internet hate speech, including hyperlinks to pages that contain offensive content. Specifically, it bans

\footnotetext{
92 European Convention for the Protection of Human Rights and Fundamental Freedoms, opened for Signature by the Council of Europe on November 4, 1950; entered into Force September 3, 1953, http://www.religlaw.org/interdocs/docs/eurconvprothr1953.htm.

${ }^{93}$ Convention on the Prevention and Punishment of the Crime of Genocide, Dec. 9, 1948, art.3(c), 78 U.N.T.S. 277, http://www.hrweb.org/legal/genocide.html.

${ }^{94}$ OSCE Conference on Anti-Semitism, Consolidated Summary (Vienna, June 19-20, 2003).

${ }^{95} \mathrm{http} / / /$ conventions.coe.int/Treaty/en/Treaties/Html/189.htm.
} 
any written material, any image or any other representation of ideas or theories, which advocates, promotes or incites hatred, discrimination or violence, against any individual or group of individuals, based on race, colour, descent or national or ethnic origin, as well as religion if used as a pretext for any of these factors. ${ }^{96}$

This is another important milestone in the combat against hate. The implementation and enforcement of this Protocol, however, depends on resources assigned to this cause by the respective governments.

At the same time I would like to emphasise that legal measures are always the last resort. Remedies which do not engage the law should be preferred to remedies requiring reliance on the law. Only if the non-legal recourses fail should be we have recourse to law.

\section{Conclusion}

Hate speech aimed at reducing an identifiable group's rights or at instigating violence against it is not a legitimate form of political discourse. It does not further democratic ideals. To the contrary, destructive messages stratify society into competing camps rather than seeking mutual grounds for compromise designed to benefit all the various factions of the society while respecting the individual rights of its members. Unrestrained bias foments disunion and endangers the civil liberties guaranteed under

\footnotetext{
${ }^{96}$ Additional Protocol to the Convention on cybercrime, concerning the criminalisation of acts of a racist and xenophobic nature committed through computer systems (Strasbourg, 28.I.2003), http://conventions.coe.int/Treaty/EN/Treaties/html/189.htm.
} 
the Constitution. More and more, the Internet is being used to undermine democracy by providing a far reaching medium for drawing together distantly situated hate groups. ${ }^{97}$

The Internet's short history provides us a crash course in understanding why a balanced approach is needed to address and resolve conflicting freedoms. Here I would like to invoke Aristotle's Rule of the Golden Mean, that for every polarity there is a mean which when practiced are good benchmarks for a life of moderation. The more we see the golden mean in each polarity, the better we find the true benchmarks of a life of wellness. ${ }^{98}$ People have the freedom to express themselves, within reason. Two underpinning principles, in the heart of liberal democracy, are respect for others, and not harming others. ${ }^{99}$ We should strive to uphold them also on the Internet.

Consequently, some limits need to be enforced. Ethics is not only a question of dealing morally well with a given world. It is also one of constructing the world, improving its nature, and shaping its development in the right way. ${ }^{100}$

\footnotetext{
${ }_{97}$ Alexander Tsesis, “Prohibiting Incitement on the Internet," Virginia J. of Law and Technology, Vol. 7, Issue 2 (summer 2002): 5.

98 http://www.odemagazine.com/blogs/roundtable/316/the_wisdom_of_aristotle_s_golden_mean

99 R. Cohen-Almagor, The Boundaries of Liberty and Tolerance (Gainesville, FL: The University Press of Florida, 1994), and Speech, Media, and Ethics (Houndmills and New York: Palgrave-Macmillan, 2005).

${ }^{100}$ Luciano Floridi and J.W. Sanders, "Internet Ethics: The Constructionist Values of Homo Poietcus," in Robert J. Cavalier (ed.), The Impact of the Internet on Our Moral Lives (Albany: State University of New York Press, 2005), pp. 195-196.
} 
The Internet is universal in nature but societies do not adopt a universal common denominator to define the boundaries of freedom of expression. These boundaries vary from one society to another, and are influenced by historical circumstances and cultural norms. Germany, Israel and countries that were under the Nazi occupation are far more sensitive to National Socialism than the United States, and rightly so. While the United States protects Nazi speech, racism and Holocaust denial, we would be most troubled if Germany were not to adopt restrictive measures against Internet sites that promote National Socialism and that deny the Holocaust.

To address the challenge of hate on the Net there is a need to exchange information in order to enhance the effectiveness of human rights-ISPs-State cooperation; lobby for international awareness about the harms and abuse of technology; helping support groups and institutions that want to set up tip-lines alerting about hate; advance our knowledge of emerging social nettherrkinge amodealky

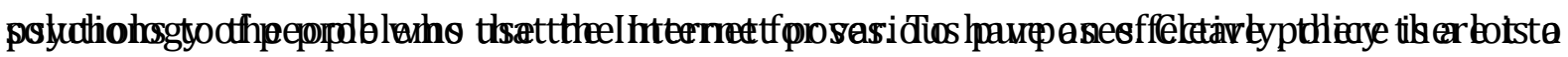

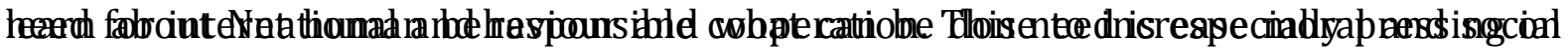

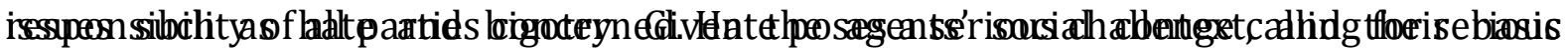

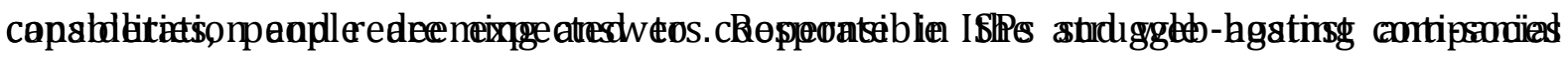
shtiuld eweighhenatagaithst the other freedom of expression and social responsibility, investing in more efforts to clean their services from Nethate. 